\title{
EVALUASI KESESUAIAN LAHAN PERTANAMAN KARET di AFDELING III PTPN VII (Persero) UNIT USAHA KEDATON
}

\author{
Maya Puspitasari, Tamaluddin Syam, Rusdi Evizal \& Ali Kabul Mahi \\ Jurusan Agroteknologi, Fakultas Pertanian Universitas Lampung \\ Jl. Prof. Sumantri Brojonegoro No.1 Bandar Lampung 35145 \\ E-mail: puspitasarimaya@ymail.com
}

\begin{abstract}
ABSTRAK
Karet adalah salah satu komoditas perkebunan unggulan Provinsi Lampung yang tersebar hampir diseluruh Kabupten di Provinsi Lampung. Tahun 2010 pertanaman karet di Provinsi Lampung seluas 119.83 ha dengan total produksi 72.240 ton. Untuk mencapai produksi yang maksimal, maka suatu jenis tanaman harus ditanam pada tempat yang sesuai dengan persyaratan tumbuhnya. Dengan evaluasi kesesuaian lahan dapat diketahui kesesuaian suatu wilayah untuk tanaman karet serta kelayakan secara ekonomi. Penelitian dilakukan dengan pendekatan penilaian kesesuaian lahan kualitatif berdasarkan kriteria Djaenuddin dkk 2000 dan evaluasi kuantitatif adalah analisis finansial dengan menghitung NPV, Net B/C, IRR, dan BEP. Penelitian dilakukan pada lahan pertanaman karet di Field 2005 E PTPN VII (Persero) Unit Usaha Kedaton Way Galih Lampung Selatan pada bulan Agustus 2012. Penelitian dilaksanakan dengan metode survey dengan pendekatan evaluasi lahan secara paralel. Hasil penelitian menunjukkan bahwa lahan pertanaman karet di Field 2005 E PTPN VII Unit Usaha Kedaton Way Galih berdasarkan potensi fisik lingkungan termasuk ke dalam kelas kesesuaian lahan cukup sesuai dengan faktor pembatas ketersediaan air dan retensi hara (S2wanr) dan secara finansial layak untuk dilanjutkan dengan nilai NPV = Rp 132.281.885 ha $^{-1}, \mathrm{Net} \mathrm{B} / \mathrm{C}=2,3, \mathrm{IRR}=24,30 \% \mathrm{thn}^{-1}$, dan $\mathrm{BEP}=14$ tahun 7 bulan 12 hari.
\end{abstract}

Kata kunci : Hevea brasiliensis, kesesuaian lahan, kualitatif, kuantitatif

\section{PENDAHULUAN}

Kebutuhan karet alam maupun karet sintetik terus meningkat sejalan dengan meningkatnya standar hidup manusia. Karet merupakan kebutuhan yang penting bagi kehidupan manusia sehari-hari, hal ini terkait dengan mobilitas manusia dan barang yang memerlukan komponen yang terbuat dari karet seperti ban kendaraan, conveyor belt, sabuk transmisi, dock fender, sepatu dan sandal karet. Harga karet alam yang membaik saat ini harus dijadikan momentum yang mampu mendorong percepatan pembenahan dan peremajaan karet yang kurang produktif dengan menggunakan klon-klon unggul dan perbaikan teknologi budidaya lainnya. Pemerintah telah menetapkan sasaran pengembangan produksi karet alam Indonesia sebesar 3-4 juta ton thn ${ }^{-1}$ pada tahun 2025. Sasaran produksi tersebut hanya dapat dicapai apabila minimal $85 \%$ areal kebun karet yang saat ini kurang produktif berhasil diremajakan dengan menggunakan klon karet unggul (Anwar, 2001).

Pengembangan komoditi perkebunan menempati prioritas tinggi dalam pembangunan bidang ekonomi di Provinsi Lampung karena diharapkan sebagai penggerak perekonomian masyarakat dan sebagai salah satu subsektor penghasil devisa melalui kegiatan ekspor komoditas perkebunan. Karet merupakan salah satu komoditas perkebunan unggulan Provinsi Lampung yang tersebar hampir diseluruh Kabupten di Provinsi Lampung. Luas areal tanaman karet di Provinsi Lampung tahun 2009 mencapai 97.598 ha dengan produksi 57.938 ton (Dinas Perkebunan Lampung, 2010).

Menurut Djaenuddin dkk. (2000), karet (Hevea brasiliensis) optimum tumbuh di daerah dengan temperatur $26-30^{\circ} \mathrm{C}$, curah hujan $2.500-3.000 \mathrm{~mm}$ tahun $^{-1}$. Karet tumbuh pada berbagai tipe tanah dengan kedalaman tanah $>100 \mathrm{~cm}$, bertekstur liat sampai lempung berliat, memiliki drainase baik, reaksi tanah berkisar antara 5-6, pada lahan yang mempunyai kecuraman lereng $<8 \%$. Berdasarkan data-data di atas, maka perlu dilakukan penilaian kesesuaian lahan pada pertanaman karet di Unit Usaha Kedaton PT Perkebunan Nusantara VII (Persero) Way Galih Lampung Selatan. Unit Usaha Kedaton dengan kemiringan lereng 0-8\%, kejenuhan basa 40\%, $\mathrm{pH} 5,0$ dan curah hujan rata-rata $2.053 \mathrm{~mm} \mathrm{thn}^{-1}$. Rata-rata produksi PT Perkebunan Nusantara VII (Persero) Unit Usaha Kedaton selama lima tahun terakhir sebesar 1.392 $\mathrm{kg} \mathrm{ha}^{-1} \mathrm{thn}^{-1}$ karet kering, pendapatan sekitar 47 juta ha- 
${ }^{1}$ thn $^{-1}$ dengan pengeluaran sekitar 20 juta sampai 24 juta ha-1 tahun $^{-1}$ (PT Perkebunan Nusantara VII (Persero) Unit Usaha Kedaton, 2012).

Evalusi kesesuaian lahan merupakan tahapan penting dalam perencanaan penggunaan lahan. Dengan evaluasi kesesuaian lahan dapat diketahui kesesuaian suatu wilayah untuk berbagai komoditas dari berbagai jenis tanaman, sehingga penggunaan lahan yang terbaik pada suatu wilayah dapat diputuskan. Kesesuaian suatu wilayah terhadap komoditas tertentu dapat diperoleh dengan membandingkan persyaratan tumbuh tanaman dengan kondisi lahan. Mempelajari kualitas dan karakteristik lahan yang sesuai untuk tanaman sangat penting untuk mencapai potensi maksimal dan mutu tanaman (Hardjowigeno, 2001).

Hasil evaluasi lahan menggambarkan kesesuaian lahan untuk berbagai keperluan dan dapat diketahui hambatan dan kebutuhan biaya dalam pemanfaatan sumber daya lahan tersebut. Melalui evaluasi lahan akan dapat diprediksi berapa besar keuntungan dan bahkan kemungkinan kerugian yang didapat, baik secara fisik maupun secara sosial ekonomi (Mahi, 2005). Berdasarkan hal itu perlu kiranya mengevaluasi kesesuaian lahan secara kualitatif dan kuantitatif di PT Perkebunan Nusantara VII (Persero) Unit Usaha Kedaton Field 2005 E Afdeling III karena pada lahan ini belum pernah dilakukan, sehingga penelitian ini diharapkan dapat memberikan masukan tentang upaya pengelolaan lahan yang lebih baik dari sisi lingkungan dan secara ekonomi lebih menguntungkan. Penelitian ini bertujuan untuk mengevaluasi kesesuaian lahan kualitatif dan kuantitatif pertanaman karet (Hevea brasiliensis) Field 2005 E Afdeling III PT Perkebunana Nusantara VII (Persero) Unit Usaha Kedataon Way Galih Lampung Selatan .

\section{BAHAN DAN METODE}

Penelitian dilaksanakan pada lahan pertanaman karet di Field 2005 E PTPN VII (Persero) Unit Usaha Kedaton Way Galih Lampung Selatan, dengan luas areal pertanaman 16 ha. Penelitian dilaksanakan pada bulan Agustus 2012. Alat-alat yang digunakan antara lain, bor tanah, buku munsell soil color chart, GPS dan Clinometer.

Penelitian dilakukan dengan menggunakan metode survei dengan pendekatan evaluasi lahan secara paralel yaitu melakukan analisis kesesuaian lahan berdasarkan kriteria fisik Djaenuddin dkk. (2000), dan kriteria analisis kelayakan finansial budidaya tanaman karet dengan menilai Net Present Value (NPV), Net Beneffit Cost Ratio (Net B/C), Internal Rate of Return
(IRR), dan Break Event Point (BEP). Pelaksanaan survei dilakukan bertahap yaitu: tahap persiapan, pengumpulan data, dan analisis data.

Tahap persiapan ini merupakan tahap studi pustaka, yaitu meneliti dan mengkaji sumber-sumber pustaka tentang keadaan lokasi penelitian sehingga memperoleh gambaran umum tentang lokasi penelitian, seperti iklim, dan karakteristik lahan. Pada tahap ini dilakukan survey lapang secara kasar dan penentuan titik pengambilan contoh tanah yang mewakili secara keseluruhan berdasarkan keadaan lapang.

Data yang dikumpulkan dalam penelitian ini meliputi, data fisik primer, data fisik skunder, dan data ekonomi. Analisis kesesuaian lahan kualitatif dilakukan dengan membandingkan karakteristik lahan dengan persyaratan tumbuh tanaman karet berdasarkan kriteria Djaenuddin dkk (2000). Kemudian untuk analisis kesesuaian lahan kuantitatif yaitu dengan mengetahui tingkat kelayakan finansial usaha tani karet dilakukan analisis NPV, Net B/C, IRR, dan BEP (Ibrahim, 2003).

\section{HASIL DAN PEMBAHASAN}

Kesesuaian Lahan Kualitatif . Hasil analisis contoh tanah daerah penelitian didapatkan kriteria pada N-total, P-tersedia, Al-dd, K-dd, Na-dd, Ca-dd, Mg-dd memiliki kisaran bernilai sangat rendah. Hasil analisis contoh tanah selengkapnya terteta pada Tabel 1 . Berdasarkan hasil pengamatan dan analisis karakteristik dan kualitas lahan secara keseluruhan di daerah penelitian, didapati bahwa kelas kesesuaian lahan berdasarkan kriteria Djaenuddin dkk. (2000) termasuk ke dalam kelas kesesuaian lahan cukup sesuai dengan faktor pembatas ketersediaan air (curah hujan, lama bulan kering) dan retensi hara (kandungan C-organik) (S2wanr). Curah hujan rata-rata yang dikehendaki oleh tanaman karet adalah sebesar 2.500-3.000 mm dan bulan kering sebesar 1-2 bulan tiap tahunnya, dikatakan masa bulan kering bila curah hujan $<60 \mathrm{~mm}$ (Djaenuddin dkk., 2000). Berdasarkan data curah hujan dari PT Perkebunan Nusantara VII (Persero) Unit Usaha Kedaton Way Galih, curah hujan tahunan rata-rata daerah penelitian adalah $2.163 \mathrm{~mm}$ dan lama masa kering rata-rata 2,5 bulan dengan jumlah bulan kering berkisar $0-5$ bulan. Gambar curah hujan pada daerah penelitian tertera pada Gambar 1. Kandungan C-organik didaerah penelitian berdasarkan hasil analisis dilaboratorium adalah $0,67 \%$ sehingga menurut kriteria Djaenuddin dkk. (2000) masuk dalam kelas kesesuaian lahan cukup sesuai (S2). Faktor pembatas ketersediaan air (curah hujan, lama bulan kering) dan retensi hara (kandungan C-organik) masih dapat dibenahi dengan 
Tabel 1. Hasil Analisis Contoh Tanah Daerah Penelitian

\begin{tabular}{lcc}
\hline \multicolumn{1}{c}{ Karakteristik lahan } & Rata-rata & Kriteria \\
\hline $\mathrm{pH} \mathrm{H} \mathrm{H}_{2} \mathrm{O}$ & 5,02 & Masam \\
$\mathrm{N}-$ tot $(\%)$ & 0,07 & Sangat rendah \\
$\mathrm{P}-$ ter $(\mathrm{ppm})$ & 2,48 & Sangat rendah \\
$\mathrm{Al}-\mathrm{dd}(\mathrm{cmol} / \mathrm{kg})$ & 0,325 & Sangat rendah \\
$\mathrm{K}-\mathrm{dd}(\mathrm{cmol} / \mathrm{kg})$ & 0,05 & Sangat rendah \\
$\mathrm{Na}-\mathrm{dd}(\mathrm{cmol} / \mathrm{kg})$ & 0,01 & Sangat rendah \\
$\mathrm{Ca}-\mathrm{dd}(\mathrm{cmol} / \mathrm{kg})$ & 0,90 & Sangat rendah \\
$\mathrm{Mg}$-dd $(\mathrm{cmol} / \mathrm{kg})$ & 0,38 & Sangat rendah \\
$\mathrm{C}-$ organik $(\%)$ & 0,67 & Sangat rendah \\
$\mathrm{KTK}$ tanah & 4,89 & Sedang \\
KB $(\%)$ & 27,5 & Rendah \\
Tekstur $(\%)$ & & \\
Pasir & 53,09 & Lempung berpasir \\
Debu & 27,00 & Lempung \\
Liat & 19,91 & Lempung \\
\hline
\end{tabular}

Sumber : Hasil analisis tanah di Laboratorium Ilmu Tanah Fakultas Pertanian Universitas Lampung (2012)

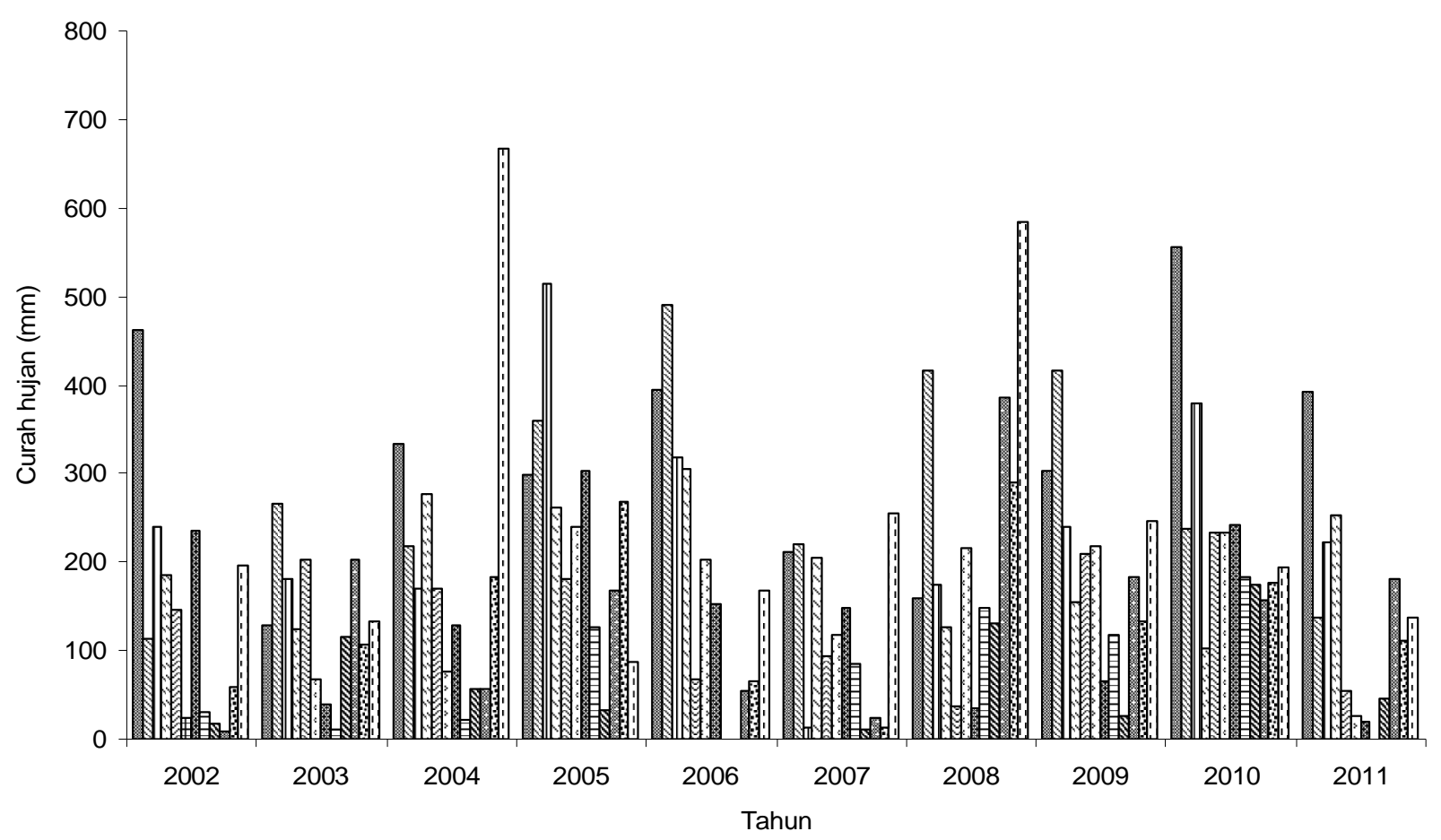

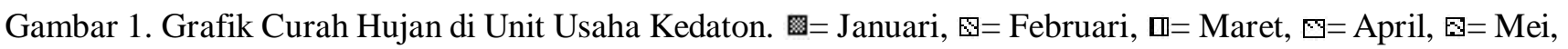

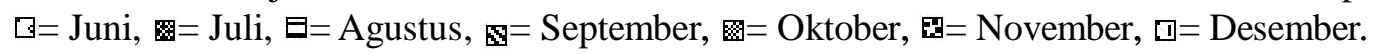

cara pembuatan lubang biopori yang merupakan solusi teknologi ramah lingkungan untuk mengatasi kurangnya ketersediaan air dengan memanfaatkan bahan organik melalui lubang kecil dalam tanah, bahan organik hasil pemangkasan Legum Cover Crop yang tersimpan didalam lubangpun dapat dijadikan sebagai sumber penghasil kompos yang dapat digunakan untuk menyuburkan tanah. Bahan organik yang berasal dari hasil pemangkasan Legum Cover Crop digunakan dalam pembuatan lubang biopori untuk memicu biota tanah seperti cacing dan semut dan akar tanaman untuk membuat rongga-rongga (lubang) di dalam tanah yang disebut biopori. Rongga-rongga (biopori) ini menjadi saluran bagi air untuk meresap ke dalam tanah. Menurut 
Kamir (2006), dengan membuat lubang resapan biopori kita dapat memaksimalkan air yang meresap kedalam tanah sehingga air hujan yang turun tidak terbuang menjadi genangan air yang dapat menimbulkan penyakit sehingga produktifitas suatu tanaman menurun. Semakin tinggi ruang pori total dan ruang pori mickro tanah, semakin tinggi kadar air tersedia tanah, bahan organik mempunyai kemampuan menyerap air sehingga tanah yang berbahan organik tinggi akan mempunyai kemampuan menyimpan air tinggi pula (Bauer dan Black 1992 dalam Murtilaksono dan Wahyuni, 2004). Kelas kesesuaian lahan untuk tanaman karet di lokasi penelitian selengkapnya tertera pada Tabel 2.

Kelas Kesesuaian Lahan Kuantitatif. Biaya produksi yang dikeluarkan petani untuk usaha tani tanaman karet terdiri dari biaya tetap dan biaya variabel. Biaya tetap adalah biaya yang besar kecilnya tidak tergantung pada produksi yang dihasilkan, dan penggunannya tidak habis dalam satu kali masa produksi. Biaya tetap terdiri dari pajak tanah dan peralatan. Biaya variabel adalah biaya yang besar kecilnya sangat tergantung pada skala produksi. Biaya variabel terdiri

Tabel 2. Kelas Kesesuaian Lahan Tanaman Karet di Daerah Penelitian

\begin{tabular}{|c|c|c|c|}
\hline No & Kualitas / Karakteristik Lahan & Nilai & KKL \\
\hline 1 & Temperatur (tc) & & \\
\hline & (Suhu tahunan rata-rata $\left({ }^{0} \mathrm{C}\right)$ & 26,43 & S1 \\
\hline \multirow[t]{3}{*}{2} & Ketersediaan air (wa) & & \\
\hline & Curah hujan (mm) tahunan & 2163,5 & $\mathrm{~S} 2$ \\
\hline & Lamanya masa kering (Bln) & 2,5 & S2 \\
\hline \multirow[t]{2}{*}{3} & Ketersediaan oksigen (oa) & & \\
\hline & Drainase & Baik & S1 \\
\hline \multirow[t]{4}{*}{4} & Media perakaran (rc) & & \\
\hline & Tekstur tanah & Sedang & S1 \\
\hline & Bahan kasar (\%) & 0 & S1 \\
\hline & Kedalaman tanah $(\mathrm{cm})$ & $>120 \mathrm{~cm}$ & S1 \\
\hline \multirow[t]{5}{*}{5} & Retensi hara (nr) & & \\
\hline & KTK liat $\left(\mathrm{cmol}_{\mathrm{c}} \mathrm{kg}^{-1}\right)$ & - & - \\
\hline & Kejenuhan basa $(\%)$ & 27,5 & S1 \\
\hline & $\mathrm{pH}$ tanah $\left(\mathrm{H}_{2} \mathrm{O}\right)$ & 5,02 & S1 \\
\hline & C- organik (\%) & 0,67 & S2 \\
\hline \multirow[t]{2}{*}{6} & Toksisitas (xe) & & \\
\hline & Salinitas $\left(\mathrm{ds} \mathrm{m}^{-1}\right)$ & $<0,5$ & S1 \\
\hline \multirow[t]{2}{*}{7} & Bahaya sulfidik (xs) & & \\
\hline & Kedalaman sulfidik (cm) & $>175 \mathrm{~cm}$ & S1 \\
\hline \multirow[t]{3}{*}{8} & Bahaya erosi (eh) & & \\
\hline & Lereng $(\%)$ & $4 \%$ & S1 \\
\hline & Bahaya erosi & $\mathrm{Sr}$ & S1 \\
\hline \multirow[t]{2}{*}{9} & Bahaya banjir (fh) & & \\
\hline & Genangan & F0 & S1 \\
\hline \multirow[t]{5}{*}{10} & Penyiapan lahan (lp) & & \\
\hline & Batuan permukaan (\%) & 0 & S1 \\
\hline & Singkapan batuan (\%) & 0 & S1 \\
\hline & Kelas Kesesuaian Lahan & & $\mathbf{S 2}$ \\
\hline & Sub Kelas Kesesuaian Lahan & & S2wanr \\
\hline
\end{tabular}

Keterangan : KKL : Kelas Kesesuaian Lahan, $\mathrm{Sr}=$ sangat ringan, $\mathrm{F} 0=$ dalam periode satu tahun tidak pernah tertutup banjir untuk waktu 24 jam. 
dari bibit, pupuk, dan tenaga kerja. Rata-rata total biaya produksi karet adalah Rp 141.467.461 ha ${ }^{-1}$ tahun $^{-1}$.

Produksi yang dihasilkan dalam usaha tani tanaman karet pada penelitian ini berupa lateks dengan pendapatan yang diperoleh tingkat petani. Tanaman karet di PT Perkebunan Nusantara VII (Persero) Unit Usaha Kedaton mulai berproduksi pada tahun keenam. Produksi lateks di lokasi penelitian relatif mengalami peningkatan. Rata-rata produksi karet $1.979 \mathrm{~kg} \mathrm{ha}^{-1}$. Data produksi lateks tahun ke-1 sampai dengan tahun ke-13 merupakan data sebenarnya yang diperoleh dari PT Perkebunan Nusantara VII (Persero) Unit Usaha Kedaton. Sedangkan untuk data dari tahun ke-14 sampai dengan tahun ke-25 merupakan data perkiraan yang diperoleh dari persamaan kuadratik $y=-12,48 x^{2}+337,3 x+489,5$. Produksi lateks terus menurun setelah tahun ke-14 sampai pada tahun ke-25. Penerimaan petani PT Perkebunan Nusantara VII (Persero) Unit Usaha Kedaton diperoleh dari penjualan lateks. Dimana mereka melakukan penjualan dengan harga yang bervariasi setiap tahunnya tergantung harga lateks pada tiap tahunnya. Total penerimaan rata-rata yaitu $\mathrm{Rp}$ 25.574.245 ha-1. Harga lateks tahun ke-1 sampai dengan tahun ke-13 merupakan data sebenarnya yang diperoleh dari PT Perkebunan Nusantara VII (Persero) Unit Usaha Kedaton. Sedangkan untuk data dari tahun ke14 sampai dengan tahun ke-25 merupakan data perkiraan yang diperoleh dari persamaan linier $\mathrm{y}=546,4 \mathrm{x}+5228$.

Berdasarkan hasil analisis evaluasi lahan kuantitatif, analisis finansial dilakukan dengan menghitung nilai penerimaan bersih sekarang, nilai perbandingan antara penerimaan bersih dan biaya serta nilai tingkat pengembalian internal dengan menggunakan tingkat suku bunga yang berlaku dimasyarakat saat ini. Tingkat suku bunga yang berlaku diasumsikan sebesar $15 \% \mathrm{thn}^{-1}$. Untuk mengetahui tingkat kelayakan usahatani tanaman karet digunakan analisis $N P V$, Net $B / C$, IRR dan BEP. Diperoleh nilai NPV (Tahun pertama - tahun ke-25) sebesar Rp 132.281.885 ha-1 yang berarti bahwa selama umur 25 tahun usahatani tanaman karet akan memberikan nilai pendapatan bersih sebesar Rp 132.281.885 ha- ${ }^{-1}$ Net B/C ratio (rasio biaya manfaat bersih) adalah perbandingan antara nilai manfaat bersih dengan biaya bersih yang diperhitungkan nilainya saat ini. Suku bunga yang diasumsikan adalah $15 \%$, Net B/C yang diperoleh adalah 2,3 , nilai IRR sebesar 24,30\% tahun ${ }^{-1}$. Hal ini menyatakan bahwa usahatani tanaman karet di PT Perkebunan Nusantara VII (Persero) Unit Usaha Kedaton Way Galih pada tingkat suku bunga $24,30 \%$ tahun $^{-1}$ masih layak untuk dikembangkan.
Nilai IRR yang didapat adalah sebesar 24,30\% tahun $^{-1}$ lebih besar dari tingkat suku bunga yang diasumsikan yaitu $15 \%$ tahun $^{-1}$ maka usahatani tanaman karet ini tidak mengalami kerugian. BEP atau titik impas dimana $T R=T C($ Total Pendapatan $=$ Total Biaya $)$ dari hasil perhitungan maka diperoleh hasil bahwa usahatani tanaman karet di Field 2005 E PT Perkebunan Nusantara VII (Persero) Unit Usaha Kedaton Way Galih akan mencapai titik impas akan selama 14 tahun 7 bulan 12 hari yang merupakan nilai BEP. Sehingga usahatani tanaman karet dilokasi penelitian memberikan keuntungan dan layak untuk dikembangkan.

\section{KESIMPULAN}

Dari hasil pengamatan di lapangan dan pengolahan data primer, maka dapat disimpulkan, kesesuaian lahan tanaman karet pada Field 2005 E Afdeling III PT. Perkebunan Nusantara (Persero) Unit Usaha Kedaton, termasuk dalam kelas kesesuaian lahan cukup sesuai dengan faktor pembatas ketersediaan air dan retensi hara (S2wanr). Hasil analisis finansial usahatani tanaman karet di PT. Perkebunan Nusantara VII (Persero) Unit Usaha Kedaton menguntungkan dan layak untuk dikembangkan. Hal ini terlihat dengan nilai penilaian selama 25 tahun yaitu NPV $=\mathrm{Rp} 132.281 .885$ $\mathrm{ha}^{-1}$, Net B/C $=2,3, \mathrm{IRR}=24,30 \%$ tahun $^{-1}$, dan BEP $=$ 14 tahun 7 bulan 12 hari.

\section{DAFTAR PUSTAKA}

Anwar, C. 2001. Manajemen dan Teknologi Budidaya Karet. Pusat Penelitian Karet. Medan.

Dinas Perkebunan Provinsi Lampung. 2010. Komoditas Perkebunana Unggul (Komoditi Karet). http:/ /disbun.lampungprov.go.id/karet.doc. Diakses 5 Januari 2013

Djaenuddin, D., Marwan, H., Subagyo, H., Mulyani, A.,dan Suharta, N. 2000. Kriteria Kesesuaian Lahan untuk Komoditas Pertanian. Departemen Pertanian. 264 hlm

Hardjowigeno, S. 2001. Kesesuaian Lahan dan Perencanaan Tataguna Tanah. Jurusan Tanah Fakultas Institut Pertanian Bogor. Bogor. 381 hlm

Ibrahim, Y. 2003. Studi Kelayakan Bisnis. Rineka Cipta. Jakarta. 249 hlm 
Kamir, R. B. 2006. Teknologi Biopori. IPB Press. Bogor. $125 \mathrm{hlm}$

Mahi, A. K. 2005. Evaluasi dan Perencanaan Penggunaan Lahan. (Diktat, tidak dipublikasikan). Fakultas Pertanian Universitas Lampung. Bandar Lampung. 240 hlm
Murtilaksono, K dan E. D. Wahyuni. 2004. Hubungan Ketersediaan Air Tanah dan Sifat-Sifat Dasar Fisika Tanah. Jurnal Tanah dan Lingkungan 6 (2) : 46-50

PT. Perkebunan Nusantara VII (Persero). 2012. Profil Unit Usaha Kedaton. PTPN VII (Persero) Unit Usaha Kedaton. Bandar Lampung 